Thorax (1974), 29, 185.

\title{
Lung volumes and flow rates in black and white subjects
}

\author{
N. L. LA P P, H . E. A MA N D U S, R. H A L L, \\ and W. K. C. MOR G A N
}

Appalachian Laboratory for Occupational Respiratory Diseases, National Institute for Occupational Safety and Health and Department of Medicine, West Virginia University School of Medicine, Morgantown, West Virginia 26505, USA

\begin{abstract}
Lapp, N. L., Amandus, H. E., Hall, R., and Morgan, W. K. C. (1974). Thorax, 29, 185-188. Lung volumes and flow rates in black and white subjects. It has been known for some time that the vital capacity and forced expiratory volume in one second of black subjects are about $12 \%$ lower than those of whites of the same age and height. In the present study, total lung capacity and residual volume were also shown to be decreased by about the same percentage. Expiratory flow rates were similarly decreased, but when the difference in lung size was evened out by matching black and white subjects of the same total lung capacity, no significant differences in flow rates were observed.
\end{abstract}

There have been several reports of different lung volumes between black and white subjects (Gould, 1869; Abramowitz, Leiner, Lewis, and Small, 1965; Densen et al., 1969). Miller, Ashcroft, Swan, and Beadnell (1970) have made similar comparison between Africans and Indians living in the Caribbean. In this regard, however, ethnic comparisons have in the main been limited to the vital capacity and its various subdivisions. Some years ago Cotes and Malhotra (1965) compared the total lung capacity (TLC) with residual volume (RV) of a group of Indians to a comparable group of Welsh miners. They demonstrated that the Welsh miners had significantly greater lung volumes. Over the past few years Cotes and his colleagues have extended their studies, and two recent papers have appeared which deal in more detail with the ethnic differences in TLC (Edwards, Miller, Hearn, and Cotes, 1972; Cotes et al., 1973). It is now quite evident that ethnic differences in total lung capacity exist. That such differences are of more than academic and anthropological interest relates to the recently introduced practice of performing preemployment spirometry in workers who, as a result of their occupation, may be exposed to bronchoconstrictive agents, e.g., cotton dust and isocyanates. If applicants were to be rejected on the usual criteria of abnormality, namely, a reduction of more than two standard deviations from the predicted value, then the fact that the forced expiratory volume in one second $\left(\mathrm{FEV}_{1}\right)$ and forced vital capacity (FVC) of the black subject are $10-15 \%$ lower than those of his white counterpart would mean that more black job applicants would be rejected.

\section{MATERIAL AND METHODS}

Between 1969 and 1971, over 9,000 coal miners were examined in the Interagency Study of Coal Workers' Pneumoconiosis. Each participant had posteroanterior and lateral chest radiographs taken. The MRC questionnaire on chronic bronchitis was completed and a detailed occupational history taken. In addition, some simple tests of ventilatory capacity were carried out. After two practice manoeuvres, three forced vital capacities were recorded as flow volume loops and the FVC and FEV 1 were taken off the tracing. The highest value for FEV 1 and FVC was accepted. Full details of the methods used are available elsewhere (Morgan, Burgess, Lapp, and Seaton, 1971). The total lung capacity (TLC) was derived by Barnhard's method (Barnhard, Pierce, Joyce, and Bates, 1960 ) and the residual volume (RV) was calculated by subtracting the FVC from the TLC. This technique has been shown elsewhere to be acceptable (O'Shea et al., 1970).

From the total population studied, 79 black (of African Negro origin) and 1,401 white coal miners were selected. Selection was based on the total absence of 'respiratory blemish'. Thus any subject with sputum, cough, or shortness of breath was rejected. All subjects with radiographic evidence of pneumoconiosis or other significant lung pathology 
were also excluded, as were subjects with an $\left(F_{1} / F V C\right) \%$ of 70 or less. Smokers were accepted owing to the difficulty of finding a sufficiently large sample of nonsmoking black miners. The fact that we used such rigid criteria does not imply that we believe the vast majority of the remainder of the participants were not healthy. We were ensuring that our sample was unaffected by environmental factors known to influence lung function.

Three whites for every black were selected for comparison of lung volumes. The two ethnic subgroups were selected at random and matched for age, height, and smoking habits, viz., smokers, nonsmokers, and former smokers. Thus a combined sample of 316 miners was selected, of which 79 were black and 237 white. FEV, FVC, RV, and TLC measurements of the two subgroups were compared, employing an analysis of variance technique, i.e., a randomized block procedure. The blocked variables were the age, height, and smoking habits of the black miners. Hence, the effects of age, height, altitude, and smoking being equal in both racial groups, differences in lung volumes might well be a consequence of inherent racial characteristics.

In a second part of the study, 66 black miners were matched with 66 white miners from the originally selected 79 blacks and 1,401 whites for the purpose of comparing expiratory flow rates at the same lung volumes. In this instance, the 66 black miners were matched one for one with a white miner on the basis of the following criteria: total lung capacity agreed to within \pm 0.01 litre, the same smoking status, the same age to within \pm 3 years, and in so far as possible, the same geographic area. The expiratory flow rates that were compared were peak flow, and flows when 50,75 , and $90 \%$ of the forced vital capacity (FVC) had been exhaled.

\section{RESULTS}

Tables I and II indicate that, on the average, the white miner has a higher FEV, FVC, TLC, and RV than does his black counterpart of the same age and height. This difference is not related to smoking. Although comparable differences between blark and white smokers and nonsmokers
T A B L E I

MEANS AND STANDARD DEVIATIONS

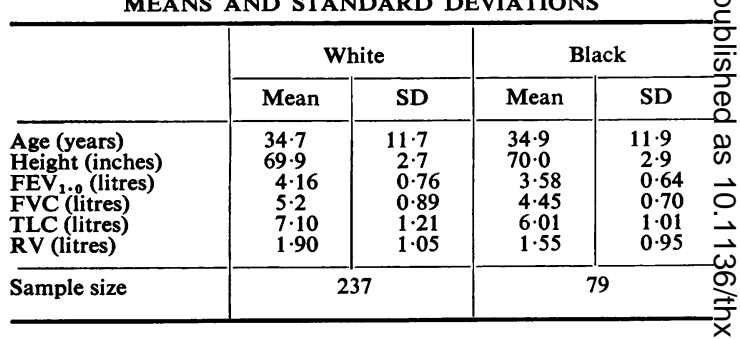

were present, no difference in pulmonary function, other than that which could be attributed too random variation, was found between the black and white ex-smokers. This is almost certainly due to the small number of ex-smoking blacks present in the sample, i.e., 11 miners. The aboveov differences were highly significant.

Regression equations for $\mathrm{FEV}_{1}, \mathrm{FVC}, \mathrm{TLC}$, and $\overrightarrow{-}$ RV for the black miners, based on age and height, were derived (Table III). Included in the ${ }^{+}$ table is the standard error of the estimates as well as the multiple correlations. Table IV shows several equations for $\mathrm{FVC}$ and $\mathrm{FEV}_{1}$ for variousō normal black populations that have been derivedo by other investigators (Abramowitz et al., 1965; Densen et al., 1969; Miller et al., 1970). For $\overrightarrow{\hat{\sigma}}$ comparative purposes, height is expressed in 3 centimetres and the equation is modified ac-? cordingly. Thus, Densen's (1969) equation for: non-white postal employees,

$$
\mathrm{FEV}_{1}=-0.44-0.0262 \text { age }+0.1314 \text { height }
$$

(in inches) $\stackrel{0}{x}$

becomes

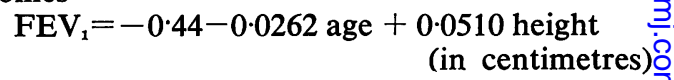

Table IV shows that there is a marked similarity of regression coefficients for age and height. The윽 equations seem to be parallel for the most part, $D$ differing only in the constant. Densen et al. (1969)을.

T A B L E I I

MEANS AND STANDARD DEVIATIONS FOR EACH RACIAL GROUP DIVIDED ACCORDING TO SMOKING CATEGORYN

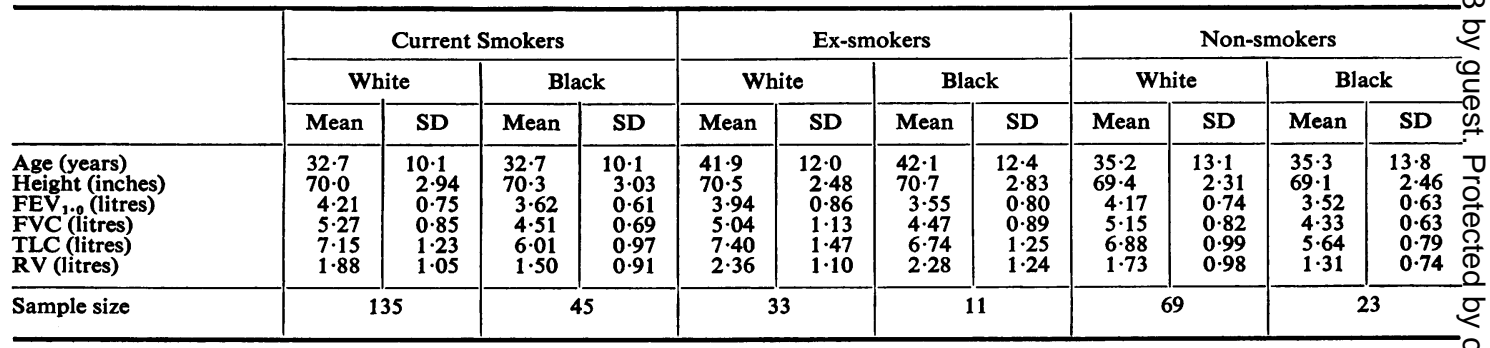


T A B L E I I I

REGRESSION EQUATIONS FOR EACH PULMONARY VARIABLE ON AGE AND HEIGHT FOR THE BLACK POPULATION

\begin{tabular}{l|c|c|c|c|c}
\hline & Constant & Age & Height & $\begin{array}{c}\text { Standard } \\
\text { Error of } \\
\text { Estimate }\end{array}$ & $\begin{array}{c}\text { Multiple } \\
\text { Correla- } \\
\text { tion }\end{array}$ \\
\hline FEV $_{1 . \text { (io (litres) }}$ & -1.54 & -0.025 & 0.09 & 0.23 & 0.67 \\
FVCC(litres) & -1.84 & -0.021 & 0.10 & 0.32 & 0.60 \\
TLC (litres) & -6.57 & 0.03 & 0.17 & 0.78 & 0.51 \\
RV (litres) & -4.73 & 0.05 & 0.07 & 0.59 & 0.60 \\
\hline
\end{tabular}

measured height in the sitting position. Since sitting height varies from one quarter to one half of standing height, Densen's regression coefficient would be between 0.1 and 0.2 if standing height were used for the prediction of $\mathrm{FEV}_{1}$; these values are similar to those in the other equations cited.

Table $\mathrm{V}$ lists the mean differences and standard deviation for the subdivisions of TLC and for the expiratory flow rates at peak, 50, 75, and $90 \%$ of FVC exhaled in the 66 pairs of black and white miners. There were no significant differences in any of these indices between the black and white miners with identical TLCs. As was expected, the black miner averaged nearly two inches taller than his white counterpart when both were matched by total lung capacity.

\section{DISCUSSION}

From this study it seems that normal black coal miners have lower lung volumes than normal white coal miners. Similar ethnic differences in various lung volumes have been noted previously (Gould, 1869; Cotes and Malhotra, 1965; Damon, 1966); however, most previous studies did not include measurements of total lung capacity and residual volume. In this regard our findings differ from those of Cotes and Malhotra (1965), who found that although Indians had a slightly smaller FEV $_{1}$ and FVC than did Europeans, the residual volumes of the two groups did not differ. Perhaps
T A B L E V

MEAN DIFFERENCES FOR LUNG VOLUMES AND FLOW RATES BETWEEN BLACK AND WHITE MINERS STANDARDIZED FOR TOTAL LUNG CAPACITY, AGE, AND SMOKING STATUS

\begin{tabular}{|c|c|c|c|}
\hline & $\begin{array}{c}\text { Black-White } \\
\text { Mean } \\
\text { Difference }\end{array}$ & SD & \\
\hline 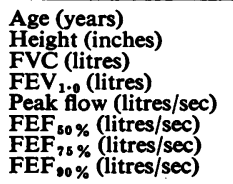 & $\begin{array}{r}0.03 \\
1.86 \\
-0.15 \\
-0.13 \\
-0.02 \\
-0.22 \\
-0.17 \\
0.03\end{array}$ & $\begin{array}{l}1.62 \\
3.80 \\
0.81 \\
0.69 \\
2.06 \\
1.73 \\
0.92 \\
0.29\end{array}$ & $\begin{array}{l}\text { NS } \\
P<0.01 \\
\text { NS } \\
\text { NS } \\
\text { NS } \\
\text { NS } \\
\text { NS } \\
\text { NS }\end{array}$ \\
\hline
\end{tabular}

the explanation for this lies in the fact that Indians and Europeans have a common Caucasian origin.

The similarity of the regression coefficients in the various prediction equations for $\mathrm{FEV}_{1}$ and FVC (Table IV) seem to indicate that within different populations of black normals, the relationship of $\mathrm{FEV}_{1}$ and FVC to age and height is nearly identical. The differences in the constant term of the equation may reflect true differences among the various populations, but they are more likely to reflect differences in the type of spirometer employed.

Several hypotheses have been put forward for the smaller lung volumes observed among black normal subjects. Gould (1869) observed that among black civil war soldiers the vital capacity was reduced as compared to white and American Indians of the same height and chest circumference. However, Damon (1966) found that black army vehicle drivers had approximately a $20 \%$ smaller chest expansion when compared to heightmatched white drivers. He also found about a $3 \%$ shorter sitting height and trunk height among the black drivers but felt this was insufficient to account for the nearly $13 \%$ difference in vital capacity. It thus appears likely that there is a difference in lung size between black and white subjects, the former having smaller lungs given

T A B L E I V

VARIOUS PREDICTION FORMULAE ${ }^{1}$ FOR FEV $_{1}$ AND FVC IN NORMAL BLACK POPULATIONS

\begin{tabular}{|c|c|c|}
\hline Author & Type of Population & Regression Equation on Height $(\mathrm{H})$ and Age \\
\hline $\begin{array}{l}\text { Abramowitz et al. (1965) } \\
\text { Miller et al. (1970) } \\
\text { This study }\end{array}$ & $\begin{array}{l}\text { Hospital employees } \\
\text { Africans } \\
\text { Working coal miners }\end{array}$ & $\begin{array}{l}\text { FVC }=-3.82+0.051 \mathrm{H}-0.018 \text { Age } \\
\text { FVC }=-2.90+0.044 \mathrm{H}-0.024 \text { Age } \\
\text { FVC }=-1.84+0.040 \mathrm{H}-0.021 \mathrm{Age}\end{array}$ \\
\hline $\begin{array}{l}\text { Miller et al. (1970) } \\
\text { Densen et al. (1969) } \\
\text { This study }\end{array}$ & $\begin{array}{l}\text { Africans } \\
\text { Non-white NY postal employees } \\
\text { Non-white NY transit workers } \\
\text { Working coal miners }\end{array}$ & $\begin{array}{l}\text { FEV } 1=-1.82+0.034 \mathrm{H}-0.024 \text { Age } \\
\text { FEV }=-0.44+0.051 \mathrm{H}-0.026 \mathrm{Age} \\
\text { FEV }_{1}=0.0083+0.047 \mathrm{H}-0.025 \mathrm{Age} \\
\text { FEV }_{1}=-1.54+0.035 \mathrm{H}-0.025 \mathrm{Age}\end{array}$ \\
\hline
\end{tabular}

${ }^{2}$ Height has been converted to centimetres when measured in inches. 
the same standing height. The black subject also has lower expiratory flow rates for the same age and height. However, when the difference in lung size was eliminated by matching black and white subjects by total lung capacity (and presumably lung size), no significant differences in expiratory flow rates were observed.

\section{REFERENCES}

Abramowitz, S., Leiner, G. C., Lewis, W. A., and Small, M. J. (1965). Vital capacity in the negro. American Review of Respiratory Diseases, 92, 287.

Barnhard, H. J., Pierce, J. A., Joyce, J. W., and Bates, J. H. (1960). Roentgenographic determination of total lung capacity. American Journal of Medicine, 28, 51 .

Cotes, J. E. and Malhotra, M. S. (1965). Differences in lung function between Indians and Europeans. Journal of Physiology, 177, $17 \mathrm{p}$.

—- Saunders, M. J., Adam, J. E. R., Anderson, H. R., and Hall, A. M. (1973). Lung function in coastal and highland New Guineans-comparison with Europeans. Thorax, 28, 320.

Damon, A. (1966). Negro-white differences in pulmonary function (vital capacity, timed vital capacity, and expiratory flow rate). Human Biology, 38, 380.
Densen, P. M., Jones, E. W., Bass, H. E., Breuer, J $\overrightarrow{\vec{F}_{0}^{*}}$ and Reed, E. (1969). A survey of respiratory disease among New York city postal and transit workers. Environmental Research, 2, 277.

Edwards, R. H. T., Miller, G. J., Hearn, C. E. D and Cotes, J. E. (1972). Pulmonary function and exercise responses in relation to body composition and ethnic origin in Trinidadian males. Proceed ${ }^{2}$ ings of the Royal Society, Series B, 181, 407.

Gould, B. A. (1869). Investigations in the Military and Anthropological Statistics of American Soldiersw Hurd and Houghton, New York.

Miller, G. J., Ashcroft, M. T., Swan, A. V., an Beadnell, H. M. S. G. (1970). Ethnic variation in forced expiratory volume and forced vitâ capacity of African and Indian adults in Guyana. American Review of Respiratory Disease, 10230 979.

Morgan, W. K. C., Burgess, D. B., Lapp, N. L., an Seaton, A. (1971). Hyperinflation of the lungs int coal miners. Thorax, 26, 585.

O'Shea, J., Lapp, N. L., Russakoff, A. D., Rege R., and Morgan, W. K. C. (1970). The deter mination of lung volumes from chest films Thorax, 25, 544.

Requests for reprints to: Dr. W. K. C. Morgare Director, Appalachian Laboratories for Occupationa Respiratory Diseases, P.O. Box 4292, Morgantowr West Virginia, 26505, U.S.A. 